\title{
Leptin secretion and leptin receptor in the human stomach
}

I Sobhani, A Bado, C Vissuzaine, M Buyse, S Kermorgant, J-P Laigneau, S Attoub, T Lehy, D Henin, M Mignon, M J M Lewin

\begin{abstract}
Background and aim-The circulating peptide leptin produced by fat cells acts on central receptors to control food intake and body weight homeostasis. Contrary to initial reports, leptin expression has also been detected in the human placenta, muscles, and recently, in rat gastric chief cells. Here we investigate the possible presence of leptin and leptin receptor in the human stomach.
\end{abstract}

Methods-Leptin and leptin receptor expression were assessed by immunohistochemistry, reverse transcriptasepolymerase chain reaction (RT-PCR), and western blot analysis on biopsy samples from 24 normal individuals. Fourteen (10 healthy volunteers and four patients with non-ulcer dyspepsia and normal gastric mucosa histology) were analysed for gastric secretions. Plasma and fundic mucosa leptin content was determined by radioimmunoassay.

Results-In fundic biopsies from normal individuals, immunoreactive leptin cells were found in the lower half of the fundic glands. mRNA encoding ob protein was detected in the corpus of the human stomach. The amount of fundic leptin was 10.4 (3.7) $\mathrm{ng}$ leptin/g mucosa, as determined by radioimmunoassay. Intravenous infusions of pentagastrin or secretin caused an increase in circulating leptin levels and leptin release into the gastric juice. The leptin receptor was present in the basolateral membranes of fundic and antral gastric cells. mRNA encoding Ob-RL was detected in both the corpus and antrum, consistent with a protein of $\sim 120 \mathrm{kDa}$ detected by immunoblotting.

Conclusion-These data provide the first evidence of the presence of leptin and leptin receptor proteins in the human stomach and suggest that gastric epithelial cells may be direct targets for leptin. Therefore, we conclude that leptin may have a physiological role in the human stomach, although much work is required to establish this.

(Gut 2000;47:178-183)

Keywords: leptin; leptin receptor; human stomach; gastrin; secretin

Leptin, the product of the $o b$ gene, ${ }^{1}$ is an adipocyte hormone which regulates energy homeostasis by informing the brain about fatty tissue mass. ${ }^{2-4}$ Injection of exogenous leptin into $o b / o b$ mice inhibits food intake and reduces body weight via activation of specific brain receptors. ${ }^{56}$ Conversely, leptin deficiency in mice and humans causes obesity and may also cause diabetes syndromes, including hyperinsulinaemia. ${ }^{78}$ Recent reports have shown that leptin inhibits insulin secretion ${ }^{9} 10$ and stimulates glucose transport and turnover in hepatocytes. ${ }^{112}$ Contrary to initial reports, leptin is not restricted to adipocytes. It has also been detected in the human placenta, ${ }^{13}$ muscles, ${ }^{14}$ and rat gastric chief cells. ${ }^{15}$ Detection of leptin in rat gastric epithelium prompted us to investigate the possible presence and role of leptin and its receptors in the human stomach.

\section{Materials and methods}

SUBJECTS

For immunocytochemical studies, 24 individuals were randomly selected from the files of our gastroenterology department (Bichat Hospital, Paris, France), these cases having been reported elsewhere. ${ }^{16}{ }^{17}$ They included 15 healthy volunteers and nine patients with non-ulcer dyspepsia $(n=24)$ who gave informed consent for upper endoscopy and gastric secretory tests.

Secretory studies available for 14 (10 healthy volunteers and four with non-ulcer dyspepsia) of the 24 subjects (mean age 45 years; range 24-60; five women, nine men) were analysed. At the time of the study all had normal endoscopy and normal gastric mucosa on histological examination. None was receiving antisecretory drugs and other drug treatments were stopped 48 hours before the secretion tests.

IMMUNOHISTOCHEMISTRY

Biopsies were performed during endoscopic examination. At least four samples were collected from antral and fundic sites. Samples were fixed in Bouin's solution or buffered formalin for 24 hours, dehydrated, and embedded in paraffin. Sections $(4 \mu \mathrm{m})$ were stained with haematoxylin-eosin-Safran to assess if the normal gastric mucosa was well oriented, and immunohistochemical staining was performed using the avidin biotin complex, diluted 1:100 (Kit ABC Vectastain; Vector Laboratories Burlington, California, USA), and diaminobenzidine to detect peroxidase activity. The antibodies used were: (a) a polyclonal antibody raised in rabbits against the carboxyl terminal frag-

Abbreviations used in this paper: RIA, radioimmunoassay; RT-PCR, reverse transcription-polymerase chain reaction; CCK, cholecystokinin. 
ment (137-156) of mouse leptin (A-20) and (b) a polyclonal antibody raised in goats against the $\mathrm{C}$ terminal fragment (1146-1165) of human leptin receptor (C-20) (Santa Cruz Biotechnology, California, USA). For leptin immunostaining, antileptin antibody was diluted 1:50 and sections were incubated for one hour at $37^{\circ} \mathrm{C}$ using a microwave method. For leptin receptor, antireceptor antibody was used at a dilution of $1: 25$ or 1:50 on tissue previously digested with $0.1 \%$ pepsin in $0.01 \mathrm{~N} \mathrm{HCl}, \mathrm{pH}$ 2.25 , for eight minutes at room temperature to retrieve antigen. Then, incubation was performed overnight at $4^{\circ} \mathrm{C}$. For controls, no immunostaining was observed in gastric tissues under the following conditions: (a) omission of the primary antibody, (b) for leptin receptor only, normal goat serum used in place of immune goat serum; (c) overnight prior incubation of the antileptin antibody with 40 $\mu \mathrm{g}$ of the homologous peptide per $\mathrm{ml}$ of diluted antiserum at $4^{\circ} \mathrm{C}$; and (d) prior incubation of antireceptor antibody with $40 \mu \mathrm{g}$ of homologous peptide per $\mathrm{ml}$ of diluted antiserum for 3-4 hours at room temperature.

Sections of fatty tissues were fixed in the same way and were used as positive controls for leptin immunostaining.
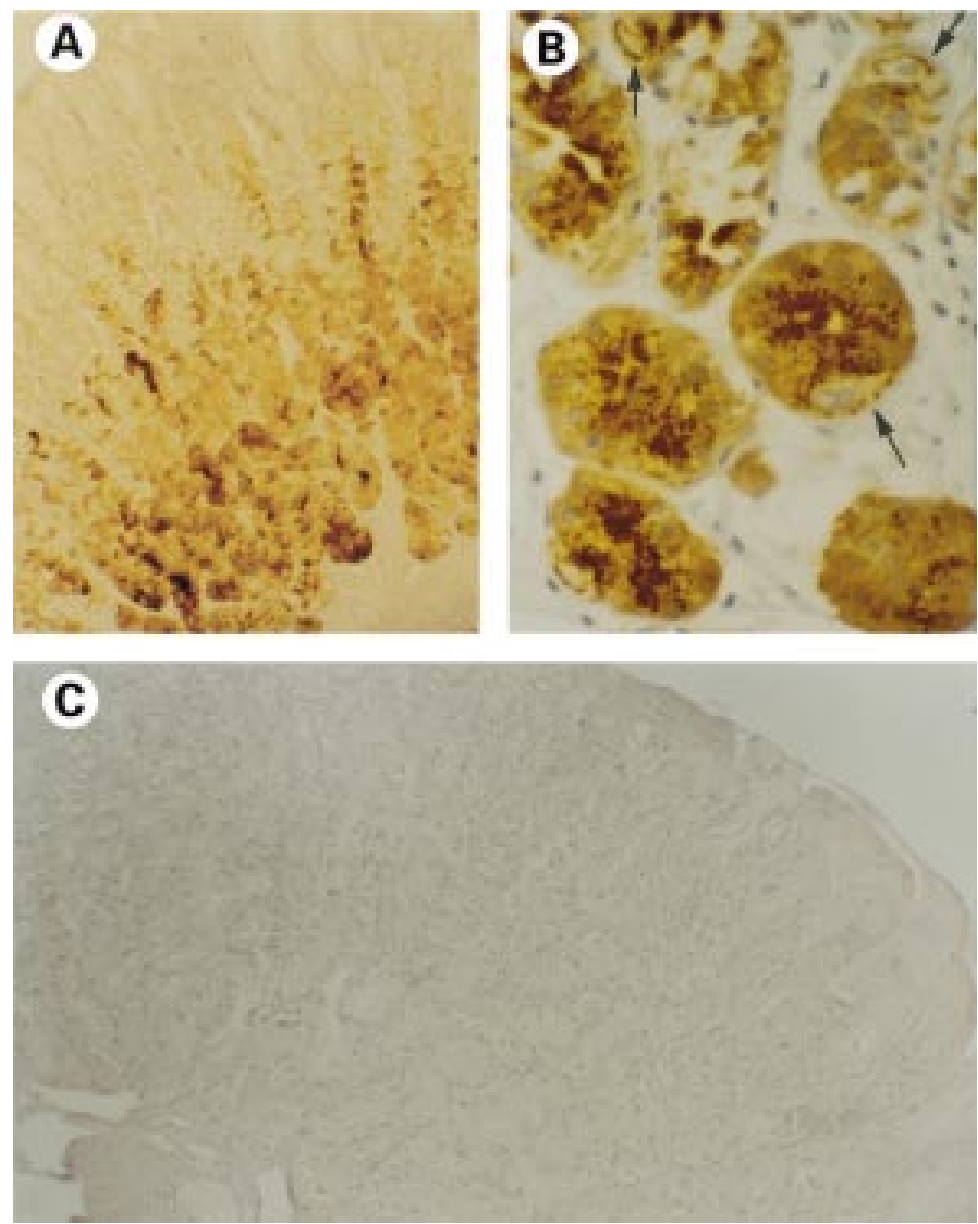

Figure 1 Leptin immunostaining in normal human fundic mucosa (Bouin's fixed, paraffin embedded tissue sections). (A) Leptin immunoreactive cells are present in the lower half of the fundic epithelial glands. (B) High magnification of leptin containing cells: leptin immunostaining was visible in the canaliculi of the parietal cells (arrows). (C) Serial section of the same region: no immunoreactivity after adsorption of the antiserum with $40 \mathrm{\mu g} / \mathrm{ml}$ of leptin fragment (137-156).
Table 1 Characteristics of the 14 healthy individuals in the gastric secretion studies

\begin{tabular}{lll}
\hline & $\begin{array}{l}\text { Mean } \\
\text { (SEM) }\end{array}$ & $\begin{array}{l}\text { Median } \\
\text { (range) }\end{array}$ \\
\hline Sex $(\mathrm{F} / \mathrm{M})$ & $5 / 9$ & \\
$\mathrm{BMI}\left(\mathrm{kg} / \mathrm{m}^{2}\right)$ & $26.3(3)$ & $24.2(20-31)$ \\
$\mathrm{BAO}(\mathrm{mmol} / \mathrm{h})$ & $4.9(1.2)$ & $2.1(0.7-13)$ \\
Plasma gastrin $(\mathrm{pg} / \mathrm{ml})$ & $48(5.7)$ & $57(45-85)$ \\
Plasma leptin $(\mathrm{ng} / \mathrm{ml})$ & $1.8(0.5)$ & $1.3(0.8-2.5)$ \\
Fundic leptin $(\mathrm{ng} / \mathrm{g}$ mucosa) & $10.4(1.5)$ & $9.5(7-15.5)$ \\
BLO $(\mathrm{ng} / \mathrm{h})$ & $25.2(5.2)$ & $18.8(10.7-61.2)$ \\
\hline
\end{tabular}

ॠFor women, median 22.5 (range 20-29); for men, median 24.2 (range 21-31).

BAO, basal acid output; BLO, basal leptin output; F, female; $M$, male; BMI, body mass index.

\section{GASTRIC JUICE COLLECTION AND SECRETION} TESTS

After an overnight fast, gastric juices were collected using a nasogastric tube as previously described. ${ }^{16}{ }^{17}$ The stomach was first emptied for 15 minutes and then basal gastric juice was collected by gentle manual suction every 15 minutes for one hour. Pentagastrin $(6 \mu \mathrm{g} / \mathrm{kg} / \mathrm{h})$ or secretin (3 IU $/ \mathrm{kg} / \mathrm{h}$ ) was infused for one hour. Gastric juices and blood samples were collected every 15 minutes for determination of leptin. The volume of gastric juice was measured and the acid concentration was determined by titration. Mean integrated basal acid output and stimulated acid output in millimoles of $\left[\mathrm{H}^{+}\right]$per hour were calculated as the sum of the four 15 minute samples. The 15 minute samples were stored at $-20^{\circ} \mathrm{C}$ until leptin assay by radioimmunoassay (RIA).

\section{GEL FILTRATION}

${ }^{125}$ I labelled human leptin $\left(\sim 6 \times 10^{4} \mathrm{cpm}\right.$; Linco Research Inc, St Charles, Missouri, USA) was incubated with or without stimulated gastric juice $(\mathrm{pH} 1.8)$ for 30 minutes at $37^{\circ} \mathrm{C}$ and eluted at room temperature from a Sephadex G-100 gel filtration column with $25 \mathrm{mM}$ phosphate buffered saline, $\mathrm{pH}$ 7.4, containing $0.01 \%$ sodium azide. Fractions $(1 \mathrm{ml})$ were collected and the radioactivity of each sample was determined. The total amount of radioactivity eluted in the peak was calculated and per cent recovery determined.

\section{LEPTIN DETERMINATION}

Leptin was measured on fundic biopsy samples from five of the 14 individuals who underwent the secretion tests. Biopsy samples were weighed and homogenised in Krebs-RingerHEPES ( $1 \mathrm{mg}$ wet weight per millilitre) with a glass Teflon homogeniser. The homogenates were centrifuged at $10000 \mathrm{~g}$ for 10 minutes. The supernatants were used for leptin assays. Fundic, plasma, and gastric juice leptin contents were estimated using a human leptin RIA kit from Linco Research Inc.

\section{PCR PRIMERS AND RT-PCR CONDITIONS}

Reverse transcription-polymerase chain reaction (RT-PCR) was performed with total RNA extracted using Trizol reagent (Gibco BRL, France) from human fundic biopsy samples. Firstly, strand cDNA was prepared from $4 \mu \mathrm{g}$ of total RNA according to the manufacturer's procedure (Pharmacia Biotech, Saclay, Orsay, 

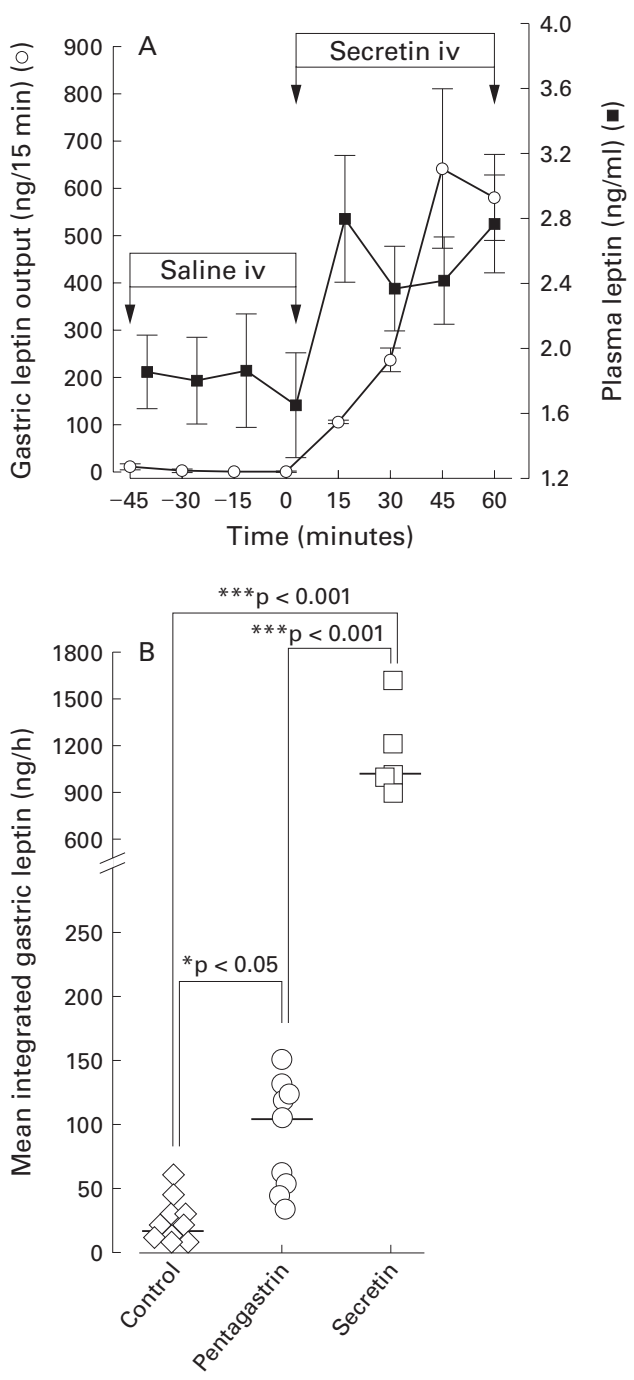

Figure 2 Effect of secretin on leptin secretion into the gastric juice and blood $(A)$, and individual integrated gastric leptin outputs (B) after pentagastrin or secretin infusion in humans. The solid line represents the median value in each group. Median (range) values are: control 18.8 (10.7-61.2) ng/h; pentagastrin 107 (39-150) ng/h; and secretin 1009 (940-1640) $\mathrm{ng} / \mathrm{h}$.

France) using murine reverse transcriptase. It was amplified by PCR using primers based on the human $o b$ and $O b-R L$ genes. The cDNA primers for the $o b$ gene were ${ }^{1}$ : f5'CCTGACCTTATCCAAG ATGG-3' and r5'GAGTAGCCTGAAGC TTCCAG-3', and for the $O b-R b \quad$ gene $^{18} \quad($ huB219.1), f5'GCCAACAACTGTGGTC TCTC-3' and r5'-AGAGAAGCACTTGG TGACTG-3'. The sample was denatured at $95^{\circ} \mathrm{C}$ for three minutes. PCR was carried out for 40 cycles of one minute denaturation at $95^{\circ} \mathrm{C}, 30$ seconds annealing at $62^{\circ} \mathrm{C}$, and two minutes of extension at $72^{\circ} \mathrm{C}$. Amplification was terminated by a final 10 minute extension step at $72^{\circ} \mathrm{C}$. In controls, RT was omitted to demonstrate that PCR amplification was not due to contamination with genomic DNA. Electrophoresis in a $1 \%$ agarose gel and ethidium bromide staining were used to verify the PCR products. The expected $224 \mathrm{bp}$ and $246 \mathrm{bp}$ were detected for the $o b$ gene and for $\mathrm{Ob}-\mathrm{Rb}$, respectively.
WESTERN BLOT ANALYSIS OF LEPTIN RECEPTORS Samples from fundic and antral biopsies, and from the entire rat brain (positive control) were weighed and immediately frozen in liquid nitrogen and stored at $-80^{\circ} \mathrm{C}$. They were homogenised at $4^{\circ} \mathrm{C}$ in RIPA buffer containing $0.1 \mathrm{mg} / \mathrm{ml}$ PMSF, $100 \mu \mathrm{M}$ benzamidine, and $100 \mathrm{mM} \mathrm{Na}_{3} \mathrm{VO}_{4}$ as protease inhibitors. They were resolved on $7.5 \%$ SDS-PAGE gel electrophoresis after loading 20-40 $\mu$ g of total protein. Protein bands were transferred to nitrocellulose sheets and probed with polyclonal antileptin receptor antibody C-20 or K-20 (Santa Cruz Biotechnology). The specificity of the immunoreactive bands was verified by preincubating the antibodies overnight with $40 \mu \mathrm{g}$ of their homologous peptide. The immune complex was revealed by an enhanced chemiluminescence detection system (Amersham, France).

RADIOIMMUNOASSAY FOR GASTRIN

A gastrin RIA (Gammadab, New York, USA) with a polyclonal antibody directed against the $\mathrm{COOH}$ terminal fragment of G-17 and G-34 was used. Serum gastrin levels were determined before and one hour after the pentagastrin or secretin infusion tests.

STATISTICAL ANALYSIS

Results are expressed as mean (SEM) or median (range) for individuals, or the mean value in each test period was used for statistical comparisons. Acid and leptin secretions under basal conditions were compared with those during pentagastrin and secretin stimulation using the Mann-Whitney $U$ test with significance at $\mathrm{p}<0.05$.

\section{Results}

LEPTIN EXPRESSION IN NORMAL GASTRIC MUCOSA In all specimens of normal human gastric mucosa, leptin immunoreactive cells were detected in the fundic epithelium. They were concentrated in the lower half of the glands at a site similar to that of chief cells, as shown in rats (fig 1A). Leptin immunostaining was also strong in the canaliculi of the parietal cells (fig 1B). The staining was leptin specific as it

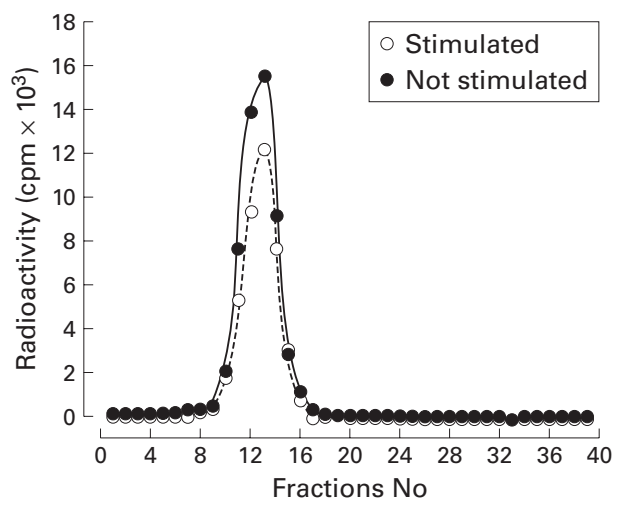

Figure 3 Sephadex G-100 elution profiles after incubation of ${ }^{125}$ I labelled human leptin with or without pentagastrin stimulated gastric juice ( $p H$ 1.8) for 30 minutes at $37^{\circ} \mathrm{C}$. A typical experiment is shown; the three experiments performed show a single peak under both sets of conditions. 
disappeared if the antibody was adsorbed onto the antigen fragment before use (fig 1C). No leptin immunoreactive cells were detected in the antrum (not shown). RIA determinations for fundic biopsies showed a mean of 10.4 (3.7) ng leptin/g mucosa for five subjects (table 1).

LEPTIN SECRETION INTO THE BLOOD AND GASTRIC JUICE OF NORMAL SUBJECTS

Leptin was detected in gastric juice at basal concentrations of $0.2-0.6 \mathrm{ng} / \mathrm{ml}$ (mean 0.3 (0.04) $\mathrm{ng} / \mathrm{ml}$ ). Basal leptin output was 25.2 (5.2) $\mathrm{ng} / \mathrm{h}$ (table 1). Secretin infusion increased
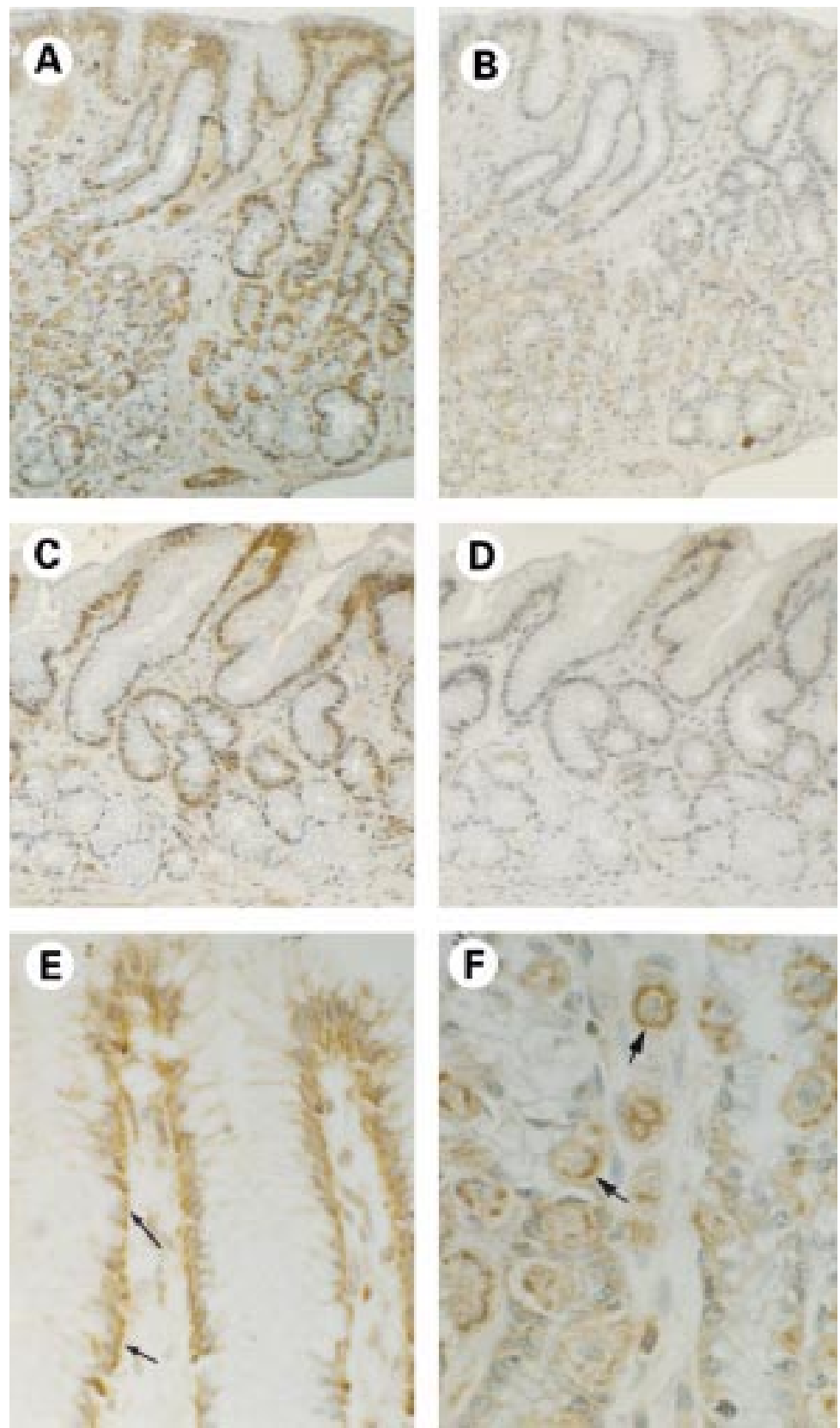

Figure 4 Leptin receptor immunostaining in normal human gastric mucosa. Tissues sections were fixed in Bouin's solution and embedded in paraffin. Nuclei were counterstained with Mayer's haemalum. (A) Fundic mucosa and (C) antral mucosa. Immunostaining was detected in superficial and pit epithelial mucous cells in the two mucosae and in fundic parietal cells; (B) and (D) are adjacent sections. The signal is much weaker and even absent if the antibody is adsorbed with the antigen. (E) Detail of immunostaining located on the lateral and particularly the basal (arrows) membranes in superficial and crypt mucous cells. (F) Detail of parietal cells; a strong signal is visible in sections of microcanaliculi.
A

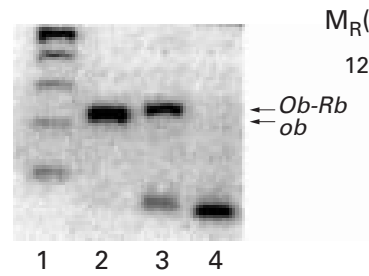

B

Figure 5 Leptin and leptin receptor expression in the human stomach. (A) Reverse transcription-polymerase chain reaction (RT-PCR) analysis of $m R N A$ : lane 1, marker ladders; lane 2, leptin mRNA in fundic epithelium; lane 3, leptin receptor $m R N A$; lane 4, reverse transcriptase omission. Expected sizes for PCR products: 224 bp for leptin and $246 \mathrm{bp}$ for human leptin receptor. (B) Western blot of leptin receptor with antibodies $K-20$ and $C-20$ in fundic

$(F)$ and antral $(A)$ extracted total proteins from human gastric biopsies and from rat brain $(\mathrm{Br})$ as a positive

control. A representative immunoblot with antibody $\mathrm{K}-20$ is shown. One leptin receptor immunoreactive band with a molecular size of about $120 \mathrm{kDa}$ was detected.

circulating plasma leptin levels by $28 \%$, which paralleled the increase in leptin output in gastric juice, reaching a mean value of 1165.8 (130.1) ng/h. Intravenous infusion of pentagastrin also significantly increased leptin output in gastric juice to a mean of $91.7(14.3) \mathrm{ng} / \mathrm{h}$ (fig $2 \mathrm{~A})$. This was accompanied by a $25 \%$ increase in circulating plasma leptin $(1.8(0.5) \vee 2.4$ (0.3) $\mathrm{ng} / \mathrm{ml} ; \mathrm{p}<0.05)$. The secretin induced increase in leptin output in gastric juice was markedly higher than that induced by pentagastrin infusion (1165.8 (130.1) v 91.7 (14.3) $\mathrm{ng} / \mathrm{h} ; \mathrm{p}<0.001$ ) (fig 2B). Secretin inhibited acid secretion but circulating gastrin levels were unaffected (data not shown).

STABILITY OF LEPTIN IN GASTRIC JUICE

Figure 3 shows a representative elution profile for Sephadex G-100 gel filtration of ${ }^{125}$ I leptin incubated for 30 minutes with or without stimulated gastric juice ( $\mathrm{pH}$ 1.8). ${ }^{125} \mathrm{I}$ labelled human leptin eluted in one peak and showed no apparent dissociation because $80 \%$ was recovered from gel filtration. Leptin was incubated with gastric juice and subjected to gel filtration. One peak was eluted in the bed volume suggesting that leptin was not associated with macromolecules or proteolytically degraded.

\section{LEPTIN RECEPTOR EXPRESSION IN GASTRIC}

MUCOSA

Leptin receptors were detected in fundic and antral epithelial cells (fig 4). Staining was more intense in superficial and pit cells than in glandular cells. It was restricted to the basolateral membrane and, in the fundic mucosa, to parietal cells, with a stronger signal on sections of the microcanaliculi in some but not all parietal cells. Prior immunoadsorption of the antibody with the corresponding antigen resulted in a reduction in or total abolition of immunostaining of the membrane and parietal cells, except for the microcanaliculi where it was only slightly decreased. However, there was no staining if the primary antibody was omitted, and very weak diffuse background staining throughout the tissue with no particular staining of the microcanaliculi if the corresponding 
normal serum was used rather than primary antiserum.

RT-PCR AND WESTERN BLOT ANALYSIS

Finally, mRNA encoding ob protein was detected only in the corpus while mRNA encoding $\mathrm{Ob}-\mathrm{R}_{\mathrm{L}}$ was detected both in the corpus and antrum of the human stomach (fig 5A). Western blot analysis of total protein with two independent antibodies for leptin receptor showed an immunoreactive band with a predicted size of $\sim 120 \mathrm{kDa}$ in the corpus and antrum (fig 5B).

\section{Discussion}

We have shown that leptin and its receptor are present in the human gastric mucosa and provide the first evidence that leptin is a stomach derived protein in humans. In addition, leptin mRNA was found and leptin containing cells were restricted to the lower half of the fundic glands at a site similar to that of the pepsinogen secreting chief cells, as previously found in rats. ${ }^{15}$ In contrast with the results obtained in rat gastric mucosa, we detected additional immunoreactivity on the parietal cell canaliculi that was abolished by immunoadsorption. This suggests simple accumulation of luminally secreted leptin in the acidic compartment of the parietal cell or alternatively, binding of leptin to receptors on parietal cell microcanaliculi.

The amount of gastric leptin determined by RIA was twice that reported for rats. Gastric leptin is simultaneously released into the blood and gastric juice by pentagastrin and secretin. These data are consistent with results in rats showing that cholecystokinin (CCK) causes a significant decrease in fundic leptin content. Secretin stimulation of gastric leptin output is not dependent on gastric acid secretion. Indeed, secretin inhibited acid secretion consistently in previous reports in rats, ${ }^{19}$ dogs, ${ }^{20}$ and humans ${ }^{21}$ but had no effect on circulating gastrin levels. Thus this effect is probably a direct effect of secretin on gastric chief cells, consistent with the presence of secretin receptors on these cells and the efficacy of secretin for stimulating pepsinogen secretion. ${ }^{22}{ }^{23}$

The leptin receptor was detected on the basolateral membranes of epithelial fundic and antral cells. However, an additional signal was detected on sections of the parietal cell canaliculi in the fundic mucosa. The reason for this is unclear. Prior immunoadsorption of the antibody with the corresponding antigen abolished basolateral staining thereby supporting its specificity. Staining of parietal cell canaliculi was not completely abolished by antigen adsorption, even if other controls were negative. Therefore, whether the leptin receptor is really present on the apical membrane invagination of the parietal cells requires further investigation.

Several isoforms of the leptin receptor generated by alternative mRNA splicing have been previously reported. ${ }^{56}$ One short form was detected in almost all tissues whereas the longest form, $\mathrm{Ob}-\mathrm{Rb}$, was found to be highly expressed in the hypothalamus ${ }^{6}$ and also in some peripheral tissues. ${ }^{18242526}$ In this study, a protein of approximately $120 \mathrm{kDa}$ was detected by immunoblotting in both the normal corpus and antral gastric mucosa of humans. This protein is the same size as the $\sim 120 \mathrm{kDa}$ protein detected in pancreatic islets transfected with $\mathrm{Ob}-\mathrm{Rb} \mathrm{cDNA}$ to overproduce wild-type Ob-Rb. ${ }^{27}$ It is also consistent with previous studies showing that there are multiple mRNA splicing variants for the leptin receptor in the stomach. ${ }^{28}$ In total, our findings clearly support the conclusion that human stomach expresses the longest form of the leptin receptor (Ob-Rb).

It is thought that only the $\mathrm{Ob}-\mathrm{Rb}$ receptor, which contains the box 1 and box 3 motifs, activates the JAK/STAT cascade, mediating the biological effects of leptin. ${ }^{29-32}$ Therefore, our findings suggest that human gastric epithelial cells are direct targets for gastric leptin. It is not known if activation of these putative targets involves luminal, endocrine, or paracrine pathways. However, the presence of the receptors on the basolateral side suggests an endocrine and/or paracrine pathway but further investigations are required to resolve this issue.

In terms of physiological function, gastric leptin may be involved in the short term control of satiety, acting in synergy with CCK via vagal afferent fibres in rat. ${ }^{33}$ Demonstration in this study that leptin receptors are present on gastric epithelial cells in humans suggests that leptin may have an additional action on these cells which are responsible for control of their secretory function. Alternatively, leptin secreted into the gastric juice, if not degraded, may reach the intestine, having biological effects on food digestion and absorption, as recently suggested by the effects of leptin on intestinal cells. ${ }^{34}$

In summary, we have demonstrated that in the human stomach, leptin is produced by the pepsinogen secreting chief cells of the fundic mucosa. We have also provided evidence that gastric epithelial cells bear the functional leptin receptor. Thus gastric epithelial cells may be physiological targets for gastric leptin. Our findings may open a new field of investigations into the actions of leptin.

We thank Michel Saadoun and Isabelle Prevost for technical support.

1 Zhang YR, Proenca M, Maffei M, Barone L, Leopold L, Friedman JM. Positional cloning of the mouse ob gene and its human homologue. Nature 1994;372:425-32.

2 Pelleymounter MA, Cullen MJ, Baker MB, et al. Effects of the obese gene product on body weight regulation in $o b / o b$ the obese gene product on body
mice. Science $1995 ; 269: 540-3$.

mice. Science 1995; 269:540-3. Recombinant mouse OB protein: evidence for a peripheral signal linking adiposity and central neural networks. Science 1995;269:546-9

4 Halaas JL, Gajiwala KS, Maffei M, et al. Weight-reducing effects of the plasma protein encoded by the obese gene. Science 1995;269:543-6.

5 Tartaglia LM, Dembski X, Weng N, et al. Identification and expression cloning of a leptin receptor, OB-R. Cell 1995;83:1263-71

6 Lee G-H, Proenca R, Montez JM, et al. Abnormal splicing of the leptin receptor in diabetic mice. Nature 1996;379: $632-5$.

7 Montague CT, Farooqi IS, Whitehead JP, et al. Congenital leptin deficiency is associated with severe early-onset obesity in humans. Nature 1997:387:903-8.

8 Klément K, Vaisse C, Lahlou $\mathrm{N}$, et al. A mutation in the human leptin receptor gene causes obesity and pituitary human leptin receptor gene causes ob

9 Cohen B, Novick D, Rubinstein M. Modulation of insulin activities by leptin. Science 1996;274:1185-8. 
10 Muller G, Ertl J, Preibisch G. Leptin impairs metabolic actions of insulin in isolated rat adipocytes. $f$ Biol Chem

11 Kamohara S, Burcelin R, Halaas JL, Friedman JM, Charron MJ. Acute stimulation of glucose metabolism in mice by leptin treatment. Nature 1997;389:374-7.

12 Nemecz M, Preininger K, Englisch R, et al. Acute effect of leptin on hepatic glycogenolysis and gluconeogenesis in perfused rat liver. Hepatology 1999;29:166-72

13 Masuzaki H, Ogawa Y, Sagawa N, et al. Nonadipose tissue production of leptin: leptin as a novel placenta-derived hormone in humans. Nat Med 1997;3:1029-33.

14 Wang J, Liu R, Hawkins M, Barzilai N, Rosetti L. A nutrient-sensing pathway regulates leptin gene expression in muscle and fat. Nature 1998;393:684-8.

15 Bado A, Levasseur S, Attoub S, et al. The stomach is a source of leptin. Nature 1998;394:790-3.

16 Sobhani I, Denizot Y, Hochlaf S, Rigaud D, Benveniste J, Lewin MJM. Gastric secretion of platelet activating factor and precursors in healthy humans: effect of pentagastrin. and precursors in healt

17 Sobhani I, Denizot Y, Vissuzaine CH, Vatier J, Benveniste J, Lewin MJM. Significance and regulation of gastric secretion of platelet activating factor in man. Dig Dis Sci

18 Cioffi JA, Shafer AW, Zupancic TJ, et al. Novel B219/OB receptor isoforms: possible role of leptin in hematopoiesis and reproduction. Nat Med 1996;2:585-9.

$19 \mathrm{Li} \mathrm{P}$, Chang TM, Chey CH. Secretin inhibits gastric acid secretion via a vagal afferent pathway in rats. Am $\mathcal{F}$ Physio 1998;275:G22-8.

20 Chey WY, Kim MS, Lee KY, Chang TM. Secretin is an enterogastrone in the dog. Am f Physiol 1981;240:G23944.

21 You CH, Chey WY. Secretin is an enterogastrone in humans. Dig Dis Sci 1987;32:466-71.

22 Sutliff VE, Raufman JP, Jensen RT, Gardner JD. Actions of vasoactive intestinal peptide and secretion on chief cells vasoactive intestinal peptide and secretion on chief cells G96-102.
23 Raufman JP. Gastric chief cells: receptors and signaltransduction mechanisms. Gastroenterology 1992;102:699trans 710 .

24 Fei H, Okano HJ, Li C, et al. Anatomic localization of alternatively spliced leptin receptors (Ob-R) in mouse brain an other tissues. Proc Natl Acad Sci USA 1997;94:7001-5.

25 Kieffer TJ, Heller RS, Habener JF. Leptin receptors expressed on pancreatic beta-cells. Biochem Biophys Res Commun 1996;224:522-7.

26 Hoggard N, Mercer JG, Rayner DV, Moar K, Trayhurn P, Williams LM. Localization of leptin receptor mRNA splice variants in murine peripheral tissues by RT-PCR and in situ hybridization. Biochem Biophys Res Commun 1997;232: 383-7.

27 Wang MY, Koyama K, Shimabukuro M, Newgard CB, Unger $\mathrm{RH}$. Ob-Rb gene transfer to leptin-resistant islets reverses diabetogenic phenotype. Proc Natl Acad Sci USA 1998;95:714-18.

28 Wang MY, Zhou YT, Newgard CB, Unger RH. A novel leptin receptor isoform in rat. FEBS Lett 1996;392:87-90.

29 Gilhardi N, Ziegler S, Wiestner A, Stoffel R, Heim MH, Skoda RC. Defective STAT signaling by the leptin receptor in diabetic mice. Proc Natl Acad Sci USA 1996;93:6231-5.

30 Vaisse C, Halass JL, Horvath CM, Darnell JE jr, Stoffel M, Friedman JM. Leptin activation of Stat3 in the hypothalamus of wild-type and $o b / o b$ mice but not $\mathrm{db} / \mathrm{db}$ mice. Nat Genet 1996;14: 95-7.

31 Baumann H, Morella KK, White DW, et al. The full-length leptin receptor has signaling capabilities of interleukin 6-type cytokine receptors. Proc Natl Acad Sci USA 1996;93:8374-8.

32 Bjorbaek C, Uotami S, da Silva B, Flier JS. Divergent capacities of the long and short isoforms of the leptin receptor. F Biol Chem 1997;272:32686-95.

33 Barrachina MD, Martinez V, Wang L, Wei JY, Taché Y. Synergistic interaction between leptin and cholecystokinin to reduce short-term food intake in mice. Proc Natl Acad Sci USA 1997;94:10455-60.

34 Nicholas MM, Emilsson V, Liu Y-L, Cawthorne MA. Leptin Nicholas MM, Emilsson V, Liu Y-L, Cawthorne MA. Leptin
action in intestinal cells. $\mathscr{f}$ Biol Chem 1998;273:26194-201. 